Abstracta Iranica Abstracta Iranica

Revue bibliographique pour le domaine irano-aryen

Volume 32-33 | 2013

Comptes rendus des publications de 2009-2010

\title{
J. A. van den Berg. Biblical Argument in Manichaean Missionary Practice. The Case of Adimantus and
} Augustine

Christelle Jullien

\section{(2) OpenEdition \\ 1 Journals}

Édition électronique

URL : http://journals.openedition.org/abstractairanica/40812

DOI : $10.4000 /$ abstractairanica.40812

ISSN : 1961-960X

\section{Éditeur :}

CNRS (UMR 7528 Mondes iraniens et indiens), Éditions de l'IFRI

\section{Édition imprimée}

Date de publication : 1 décembre 2013

ISSN : 0240-8910

\section{Référence électronique}

Christelle Jullien, « J. A. van den Berg. Biblical Argument in Manichaean Missionary Practice. The Case of Adimantus and Augustine », Abstracta Iranica [En ligne], Volume 32-33 | 2013, document 314, mis en ligne le 01 juillet 2016, consulté le 03 octobre 2020. URL : http://journals.openedition.org/ abstractairanica/40812 ; DOI : https://doi.org/10.4000/abstractairanica.40812

Ce document a été généré automatiquement le 3 octobre 2020.

Tous droits réservés 


\title{
J. A. van den Berg. Biblical Argument in Manichaean Missionary Practice. The Case of Adimantus and Augustine
}

\author{
Christelle Jullien
}

\section{RÉFÉRENCE}

J. A. van den Berg. Biblical Argument in Manichaean Missionary Practice. The Case of Adimantus and Augustine. Leiden, 2009, 244 p. (Nag Hammadi and Manichaean Studies 70).

1 L'utilisation de la Bible par les manichéens est ici illustrée à travers les pratiques du missionnaire manichéen Adda, l'un des premiers disciples de Mani en Mésopotamie au milieu du III $^{\mathrm{e}}$ siècle. Les thématiques de ses disputationes sont reconstruites essentiellement à partir des écrits d'Augustin, qui réfuta la doctrine du manichéen (latinisé en Adimantus) sur la base d'une traduction latine de ses travaux dont disposait l'évêque d'Hippone. L'A. avance l'hypothèse d'une appartenance d'Adda au mouvement marcionite avant son intégration dans l'Église manichéenne.

\section{AUTEURS}

CHRISTELLE JULLIEN

CNRS, Mondes iranien et indien, Paris 